\title{
Yield and quality of seeds of lettuce genotypes produced under organic management ${ }^{1}$
}

\author{
Josiany Thamara Alves Souza ${ }^{2}$, Cândido Alves da Costa ${ }^{2 *}$ (D), Delacyr da Silva \\ Brandão Junior ${ }^{2}$, João Batista de Campos Menezes², Warley Marcos Nascimento ${ }^{3}$, \\ Wesley José Cardoso ${ }^{2}$
}

\begin{abstract}
Lettuce is one of the main vegetable species used in organic production. However, studies and research in the organic area are scarce. This study aimed to evaluate the yield and quality of seeds of lettuce genotypes produced in two consecutive years under an organic management system. Two plantations were installed under open field conditions corresponding to autumn/winter in 2016 and 2017. Ten lettuce genotypes were evaluated in four replications using a biofertilizer made from swine manure in the management and manual harvesting of seeds. Evaluations consisted of seed yield (in kg.ha $\mathrm{h}^{-1}$ ), physical test (1000-seed weight), and germination and vigor test (first germination count, germination rate index, and seedling dry matter). The genotype Cubana and two Grand Rapids had higher yields under the tested conditions. Higher seed weights were recorded in 2017. Both genotypes Grand Rapids reached the minimum germination standard established for commercialization (80\%). Vanda and AC 5058 showed a better performance for germination rate index and first germination count, while Cinderela had a better seedling dry matter. These varieties were promising for organic cultivation.
\end{abstract}

Index terms: Lactuca sativa L., vegetable, biofertilizer, agroecology.

\section{Produtividade e qualidade de sementes de genótipos de alface produzidas sob o manejo orgânico}

\begin{abstract}
RESUMO - A alface é uma das principais espécies de hortaliças utilizadas na produção orgânica, porém, os estudos e pesquisas na área de orgânicos são considerados escassos. O objetivo do estudo foi avaliar a produtividade e qualidade de sementes de genótipos de alface produzidas em dois anos consecutivos no sistema de manejo orgânico. Foram instalados dois plantios em condições de campo aberto correspondendo às estações de outono/inverno em 2016 e 2017. Avaliaram-se 10 genótipos de alface, em quatro repetições, utilizando biofertilizante suíno no manejo e colheita manual das sementes. As avaliações efetuadas foram: produtividade das sementes em kg.ha ${ }^{-1}$; teste físico (peso de 1000 sementes); teste de germinação e de vigor (primeira contagem de germinação, índice de velocidade de germinação e massa seca de plântulas). O genótipo Cubana e os dois genótipos Grand Rapids apresentaram produtividades superiores nas condições testadas. Em 2017 foram registrados maiores pesos de sementes. Os dois genótipos Grand Rapids atingiram o padrão mínimo de germinação estabelecido para a comercialização (80\%). Vanda e AC 5058 apresentaram melhores desempenho para IVG e primeira contagem, e, Cinderela para massa seca de plântulas. Tais variedades mostraram ser promissoras para o cultivo orgânico.
\end{abstract}

Termos para indexação: Lactuca sativa L., hortaliça, biofertilizante, agroecologia.

\section{Introduction}

Leafy vegetables represent $35 \%$ of the area of vegetable species produced in Brazil, and lettuce (Lactuca sativa L.) stands

\footnotetext{
${ }^{1}$ Submitted on 02/25/2019. Accepted for publication on 04/17/2019. ${ }^{2}$ Instituto de Ciências Agrárias, Universidade Federal de Minas Gerais, Caixa Postal 135, 39404-547 - Montes Claros, MG, Brasil.
}

out for being the most consumed and produced leafy vegetable, followed by arugula, cabbage, and watercress (ABCSEM, 2018).

Lettuce is propagated by seeds, whose physiological and sanitary quality is essential for a fast and uniform establishment

\footnotetext{
${ }^{3}$ Embrapa Hortaliças, Caixa Postal 218, 70275-970 - Brasília, DF, Brasil. *Corresponding author <candido-costa@ufmg.br>
} 
in the field, being one of the factors that provide the success of the production of this vegetable (Nascimento et al., 2011).

The success of vegetable seeds companies is linked to factors such as availability of cultivars that usually come from plant breeding programs, climate conditions according to the specificity of each cultivar, and seed production technology. All these factors influence in obtaining high-quality seeds, considering genetic, physical, physiological, or sanitary aspects (Nascimento and Melo, 2015).

Because lettuce seed production in Brazil is carried out at the full sun, production sites are climate dependent, requiring a well-defined dry season, which should coincide with the harvest. Northern Minas Gerais State presents a semiarid climate, defined dry seasons, and mean annual temperatures relatively high, with periods of mild temperatures. These characteristics, combined with the use of an irrigation system, favor seed production of most vegetables.

Lettuce is one of the main vegetable species used for organic production. However, in spite of its pioneering in organic production, as well as the growing demand for organic products, the share of vegetables in the organic market in Brazil is still incipient, representing only $1.8 \%$ of the total area cultivated and certified in 2013, according to the Ministry of Agriculture, Livestock and Supply (Brasil, 2014). Also, these products have higher added value and, on average, exceed the values of conventional vegetables by $30 \%$ (Brasil, 2015).

This crop presents, besides economic importance, an important social role as it is cultivated mainly by micro and small farmers and commercialized directly in the farmers market.

Although the high technology in the production of some vegetable species, with production throughout the year in the most diverse regions of Brazil, vegetable seed production technology still requires investment in research (Nascimento and Melo, 2015), such as in the segment of organic seed production. Considering the reports on the contamination of vegetables with phytosanitary products, organic products have been considered more reliable for consumption (Sediyama et al., 2014).

The study of seeds based on organic production for seed production is still incipient, with no recommended varieties for organic cultivation. Thus, this study aimed to evaluate the yield and quality of seeds of lettuce genotypes during two consecutive years under an organic management system.

\section{Material and Methods}

Two experiments were conducted during autumn/winter, both planted in June in an area of non-conventional vegetables of the Instituto de Ciências Agrárias of Universidade Federal de Minas Gerais (UFMG), located in Montes Claros, northern
Minas Gerais, Brazil.

According to Koppen classification, the regional climate is Aw, considered a tropical savanna climate with a dry winter and rainy summer, and temperatures ranging from 15 to $35^{\circ} \mathrm{C}$. Before soil tillage, soil samples were collected at a depth of 0 to $20 \mathrm{~cm}$ in the experimental area.

Ten genotypes of crisp lettuce were evaluated, seven of them originated from the germplasm bank of Empresa Brasileira de Pesquisa Agropecuária (Embrapa) Vegetables (Grand Rapids, Cubana, Vanda, AC 5058, AC 5053, and two AC 5056, one with light and other with dark seeds) and the other three obtained from commercial centers of the city (Grand Rapids, Mônica and Cinderela).

Seedlings were produced in polyethylene trays, sown about 30 days before transplanting. Thinning and transplanting operations were carried out whenever necessary.

Soil tillage was carried out with plowing and harrowing. The organic management consisted of an application in total area on the soil (planting fertilization) and foliar applications (broadcast fertilization) of a biofertilizer made with swine manure, as well as manual weeding and Metarhizium application.

Biofertilizer application was conducted about 30 days before transplanting in the field. The dose applied to the soil was calculated based on the phosphorus content, considering its concentration in the biofertilizer and recommendations of phosphate fertilization for the lettuce crop in the Minas Gerais State according to soil P content (CFSEMG, 1999).

The experiments were conducted in the field in a randomized block design with ten treatments (genotypes) and with four replications, totaling 40 plots. Four rows with an interrow spacing of $0.8 \mathrm{~m}$ and $0.5 \mathrm{~m}$ between plants were cultivated in both experiments. The four plants located at the center of the two central rows of each experimental plot were considered as the useful plot to be evaluated.

Manual weeding operations were carried out during the experimental period in order to avoid competition with weeds, especially in the initial stages of the plants. Irrigation was performed with a micro-sprinkler system according to crop recommendations, being interrupted at the flowering stage. Foliar applications of biofertilizer and Metarhizium were carried out with a knapsack sprayer. For this, $10 \mathrm{~mL}$ of biofertilizer was diluted in $10 \mathrm{~L}$ of water, while $10 \mathrm{~g}$ of Metarhizium was diluted in $10 \mathrm{~L}$ of water to control thrips. Diseased plants were eliminated as soon as they were identified. Plant skirts were pruned during the reproductive period to improve aeration and avoid pathogen occurrence.

Seeds were harvested manually by cutting the plants or inflorescences when they had 60 to $70 \%$ of white plumage (pappus) or by covering the inflorescences with bag and 
removing them. Harvest was divided into one to four times depending on the genotype and from September to October for the two evaluated years.

After harvesting, seeds were dried in a protected, aerated, and dry environment. Threshing was performed manually, consisting of hitting the plants against an uneven surface. Cleaning was carried out to eliminate impurities next to the seeds using sieves and a blower, an equipment used to separate forage seeds and that was adapted to facilitate the cleaning of lettuce seeds. These seeds were then taken to the Laboratory of Seed Analysis (LAS) of the Institute of Agricultural Sciences (ICA).

After the seeds were cleaned, the percentage of purity was determined according to the Rules for Seed Testing to assist in determining yield. The determination of this purity consisted of weighing approximately $3.0 \mathrm{~g}$ of seeds of each useful plot. The pure seeds were separated from impurities and weighed. According to the initial weight (seeds + impurities), the purity percentage ratio was found for the sample.

According to the weight of useful plants (four plants), the relationship was carried out for each plot (16 plants) and area (166 plants), thus determining the yield of the area $(\mathrm{g})$ and then seed yield per hectare $\left(\mathrm{kg} \cdot \mathrm{ha}^{-1}\right)$. Yield values were calculated from impurity-free seeds to avoid that a certain genotype had higher or lower yield according to the amount of impurities present in the samples.

The variable one thousand-seed weight was calculated according to Brasil (2009). Seeds of each four plants that composed the useful plots were weighed, and seed weight was calculated in $\mathrm{kg} \cdot \mathrm{ha}^{-1}$ according to the number of plants of the used spacing.

The germination test was performed with four replications of 50 seeds per treatment arranged in gerbox boxes on two sheets of blotting paper moistened with 2.5 times their dry weight of distilled water. Subsequently, the gerbox boxes were placed in a germination chamber (BOD) at $20^{\circ} \mathrm{C}$ for seven days to determine the percentage of seed germination according to the amount of normal germinated seedlings.

The first germination count was determined by registering the percentage of normal seedlings on the fourth day after the test was installed (Brasil, 2009), being carried out together with the germination test and the germination rate index (GRI), which was calculated according to Maguire (1962) by daily counts of germinated seedlings until the seventh day after sowing (Nakagawa, 1999).

Seedling dry matter was determined after drying the plants in a forced air circulation oven at $65{ }^{\circ} \mathrm{C}$ for 72 hours, followed by weighing on a precision scale.

The data were submitted to analysis of joint variance. The data of germination rate index and first germination count were transformed into arcsine of the square root of $x / 100$. The Scott Knott test at $5 \%$ probability was used for grouping the means in case of significant effect, according to the F-test for treatments.

\section{Results and Discussion}

In the first year of planting, all genotypes presented better yield results when compared to the second year. Only Vanda and AC 5056 with dark seeds maintained similar yields regardless of the year of planting (Table 1).

Lettuce yields vary greatly depending on the cultivar, production site, and climate conditions and changes may occur from year to year in the same period, affecting plant behavior. Viggiano (1990) recommended sowing in periods of milder temperatures to favor the growth of the vegetative stage before the reproductive stage begins. Higher temperatures occurred in 2016 during the reproductive stage, which favored a better seed production.

Cubana and both genotypes Grand Rapids showed a better yield $\left(\mathrm{kg} . \mathrm{ha}^{-1}\right)$ in 2016. In 2017, the genotypes Vanda, both Grand Rapids, Cubana, and AC 5056 with dark seeds had better results when compared to other genotypes.

According to Viggiano (1990), the yield of cultivars can vary from 372 to $1.179 \mathrm{~kg} \cdot \mathrm{ha}^{-1}$. In the present study, Cubana, both Grand Rapids, and AC 5058 had means of yield above this minimum $\left(372 \mathrm{~kg} \cdot \mathrm{ha}^{-1}\right)$ only in the first year, and the variation to which that author referred was observed in a conventional system, whereas it occurred in an organic system in the present study.

Table 1. Means of yield $\left(\mathrm{kg} \cdot \mathrm{ha}^{-1}\right)$ of ten lettuce genotypes grown under organic management in 2016 and 2017 at UFMG.

\begin{tabular}{lcr}
\hline \multirow{2}{*}{ Genotype } & \multicolumn{2}{c}{ Means } \\
\cline { 2 - 3 } & 2016 & \multicolumn{1}{c}{2017} \\
\hline Grand Rapids (Embrapa) & $489.61 \mathrm{aA}$ & $255.40 \mathrm{aB}$ \\
Grand Rapids (commercial) & $491.17 \mathrm{aA}$ & $270.24 \mathrm{aB}$ \\
Mônica & $349.79 \mathrm{bA}$ & $79.43 \mathrm{bB}$ \\
Cubana & $562.25 \mathrm{aA}$ & $268.80 \mathrm{aB}$ \\
Cinderela & $242.42 \mathrm{bA}$ & $59.31 \mathrm{bB}$ \\
Vanda & $231.45 \mathrm{bA}$ & $270.58 \mathrm{aA}$ \\
AC5053 & $321.50 \mathrm{bA}$ & $69.86 \mathrm{bB}$ \\
AC5058 & $392.37 \mathrm{bA}$ & $95.86 \mathrm{bB}$ \\
AC 5056 (light seed) & $280.12 \mathrm{bA}$ & $152.67 \mathrm{bB}$ \\
AC 5056 (dark seed) & $331.44 \mathrm{bA}$ & $222.31 \mathrm{aA}$ \\
\hline
\end{tabular}

Means followed by the same lowercase letter in the column and uppercase letter in the rows do not differ from each other by the Scott-Knott test at $5 \%$ probability. 
Villela et al. (2010) evaluated lettuce cultivars and verified higher seed yields with the cultivar Vera (1370.31 kg.ha-1) in the fall/winter, which is a yield much higher than that found in the present study. However, these authors carried out the experiment in a greenhouse under the conventional management system, and because it is under controlled conditions, the yield is expected to be higher.

The second year presented the highest 1000-seed weights when compared to the previous year, regardless of the evaluated genotype (Table 2). Seed weight ranged from 0.30 to $0.44 \mathrm{~g}$ in the first year and 0.76 to $0.97 \mathrm{~g}$ in the second year. Villella et al. (2010) found a variation from 0.76 to $1.29 \mathrm{~g}$ for eight lettuce cultivars in the fall/winter season, results higher than those found in 2016 and similar to those in 2017.

The delay in the reproductive stage under mild temperatures, with a consequent increase in the development period of lettuce plants, facilitates the formation of a more developed photosynthetic apparatus capable of producing a higher photoassimilate flow for seeds, which are formed with higher size and density (Villela et al., 2010). This behavior occurred with the seeds in the second year.

Seed germination in the laboratory showed similar behavior in both years, except for both genotypes AC 5056, which had a performance in 2017 below that obtained in 2016 (Table 3). The germination of AC 5053 was lower than that found for other genotypes in the first year, maintaining this low performance in 2017 with the genotypes AC 5056 (Table 3).

The genotypes Grand Rapids from the Embrapa germplasm Bank in 2016 and the commercial Grand Rapids in 2017 showed germination higher than the established standard for commercialization of lettuce seeds, which is $80 \%$. Catão et al. (2014) found values higher than $80 \%$ of germination at temperatures of $20^{\circ} \mathrm{C}$ for different lettuce cultivars, among them Grand Rapids (97\%).

Lettuce presents dormancy when subjected to high temperatures, but post-harvest dormancy has not been reported. Despite this, some genotypes grown in 2016 were evaluated after six months of storage under the same conditions and presented better results in the evaluated characteristics when compared to the same genotypes not submitted to a long storage period (Table 4).

According to Taylor (1997), lettuce seeds are composed of $38 \%$ lipids. High oil contents in seeds, such as those of lettuce, favor the esterase enzyme group, which is a hydrolytic enzyme in the release of fatty acids used in alpha-beta oxidation as an energy source for germination. Esterases have specific functions in the lipid metabolism used as markers of the process of seed deterioration (Vieira et al., 2006). Thus, the study of germination of lettuce seeds with storage periods would be interesting for a better evaluation of the obtained results.

The germination rate index showed a distinct behavior for Mônica, AC 5058, and AC 5056 in both years. The other genotypes had similar indices in both years (Table 5). The genotypes AC 5056 with dark seeds, Mônica, Vanda and AC 5058 were superior to the other genotypes evaluated in 2016. However, both genotypes AC 5056 and AC 5053 were inferior to the others in the evaluation of the second planting.

Table 2. Means of 1000-seed weight ( $\mathrm{g}$ ) of ten lettuce genotypes grown under organic management in 2016 and 2017 at UFMG.

\begin{tabular}{lcc}
\hline \multirow{2}{*}{ Genotype } & \multicolumn{2}{c}{ Means } \\
\cline { 2 - 3 } & 2016 & 2017 \\
\hline Grand Rapids (Embrapa) & $0.396 \mathrm{aB}$ & $0.971 \mathrm{aA}$ \\
Grand Rapids (commercial) & $0.443 \mathrm{aB}$ & $0.925 \mathrm{aA}$ \\
Mônica & $0.310 \mathrm{bB}$ & $0.761 \mathrm{cA}$ \\
Cubana & $0.384 \mathrm{aB}$ & $0.957 \mathrm{aA}$ \\
Cinderela & $0.359 \mathrm{bB}$ & $0.806 \mathrm{cA}$ \\
Vanda & $0.347 \mathrm{bB}$ & $0.889 \mathrm{bA}$ \\
AC5053 & $0.368 \mathrm{bB}$ & $0.859 \mathrm{bA}$ \\
AC5058 & $0.361 \mathrm{bB}$ & $0.948 \mathrm{aA}$ \\
AC 5056 (light seed) & $0.335 \mathrm{bB}$ & $0.873 \mathrm{bA}$ \\
AC 5056 (dark seed) & $0.407 \mathrm{aB}$ & $0.902 \mathrm{bA}$ \\
\hline
\end{tabular}

Means followed by the same lowercase letter in the column and uppercase letter in the rows do not differ from each other by the Scott-Knott test at $5 \%$ probability.

Table 3. Means of germination (\%) of ten lettuce genotypes grown under organic management in 2016 and 2017 at UFMG.

\begin{tabular}{lcc}
\hline \multirow{2}{*}{ Genotype } & \multicolumn{2}{c}{ Means } \\
\cline { 2 - 3 } & 2016 & 2017 \\
\hline Grand Rapids (Embrapa) & $81.25 \mathrm{aA}$ & $74.50 \mathrm{aA}$ \\
Grand Rapids (commercial) & $64.00 \mathrm{aA}$ & $83.50 \mathrm{aA}$ \\
Mônica & $64.50 \mathrm{aA}$ & $66.50 \mathrm{aA}$ \\
Cubana & $58.50 \mathrm{aA}$ & $57.00 \mathrm{aA}$ \\
Cinderela & $62.75 \mathrm{aA}$ & $60.50 \mathrm{aA}$ \\
Vanda & $70.25 \mathrm{aA}$ & $76.00 \mathrm{aA}$ \\
AC5053 & $25.00 \mathrm{bA}$ & $8.00 \mathrm{bA}$ \\
AC5058 & $69.50 \mathrm{aA}$ & $45.50 \mathrm{aA}$ \\
AC 5056 (light seed) & $50.25 \mathrm{aA}$ & $19.50 \mathrm{bB}$ \\
AC 5056 (dark seed) & $74.00 \mathrm{aA}$ & $21.00 \mathrm{bB}$ \\
\hline
\end{tabular}

Means followed by the same lowercase letter in the column and uppercase letter in the rows do not differ from each other by the Scott-Knott test at $5 \%$ probability. 
Kano et al. (2006) worked with potassium doses aiming at production and quality of lettuce seeds and found a germination rate index ranging from 27.3 to 29.7 for 'Verônica.' The genotype AC 5053 presented worse results when compared to those found by these authors, i.e., 16.30 in 2016 and 3.11 in 2017. The germination rate is a very important factor for seedling survival, influencing their development (Ritter et

Table 4. Means of the physiological quality variables germination, germination rate index (GRI), first germination count (FC), and seedling dry matter (SDM) at $20^{\circ} \mathrm{C}$ of the genotypes Grand Rapids (GR), Mônica, Cubana, and Cinderela after six months of storage at UFMG.

\begin{tabular}{ccccc}
\hline \multicolumn{5}{c}{ Means } \\
\hline Genotype & $\begin{array}{c}\text { Germination } \\
(\%)\end{array}$ & GRI & FC (\%) & $\begin{array}{c}\text { SDM } \\
(\%)\end{array}$ \\
\hline $\begin{array}{c}\text { GR } \\
\text { (commercial) }\end{array}$ & $79.50 \mathrm{a}$ & $18.04 \mathrm{c}$ & $83.50 \mathrm{a}$ & $0.46 \mathrm{a}$ \\
GR & $84.50 \mathrm{a}$ & $19.42 \mathrm{c}$ & $80.50 \mathrm{a}$ & $0.47 \mathrm{a}$ \\
(EMBRAPA) & $93.50 \mathrm{a}$ & $40.72 \mathrm{a}$ & $94.00 \mathrm{a}$ & $0.32 \mathrm{ab}$ \\
Mônica & $75.50 \mathrm{a}$ & $19.27 \mathrm{c}$ & $72.50 \mathrm{a}$ & $0.01 \mathrm{a}$ \\
Cubana & $73.50 \mathrm{a}$ & $29.10 \mathrm{~b}$ & $73.00 \mathrm{a}$ & $0.00 \mathrm{ab}$ \\
\hline Cinderela & & & &
\end{tabular}

Means followed by the same letter in the column do not differ from each other by the Scott-Knott test at $5 \%$ probability.

Table 5. Means of germination rate index (GRI) of ten lettuce genotypes grown under organic management in 2016 and 2017 at UFMG.

\begin{tabular}{|c|c|c|}
\hline \multirow{2}{*}{ Genotype } & \multicolumn{2}{|c|}{ Means } \\
\hline & 2016 & 2017 \\
\hline $\begin{array}{l}\text { Grand Rapids } \\
\text { (Embrapa) }\end{array}$ & $0.692^{1}(46.33)^{2} \mathrm{bA}$ & $0.628^{1}(39.86)^{2} \mathrm{aA}$ \\
\hline $\begin{array}{l}\text { Grand Rapids } \\
\text { (commercial) }\end{array}$ & $0.691^{1}(46.69)^{2} \mathrm{bA}$ & $0.743^{1}(52.48)^{2} \mathrm{aA}$ \\
\hline Mônica & $0.846^{1}(65.52)^{2} \mathrm{aA}$ & $0.531^{1}(28.79)^{2} \mathrm{aB}$ \\
\hline Cubana & $0.631^{1}(38.95)^{2} \mathrm{bA}$ & $0.580^{1}(35.36)^{2} \mathrm{aA}$ \\
\hline Cinderela & $0.660^{1}(43.04)^{2} \mathrm{bA}$ & $0.608^{1}(39.22)^{2} \mathrm{aA}$ \\
\hline Vanda & $0.804^{1}(60.81)^{2} \mathrm{aA}$ & $0.587^{1}(34.42)^{2} \mathrm{aA}$ \\
\hline AC5053 & $0.361^{1}(16.30)^{2} \mathrm{cA}$ & $0175^{1}(3.11)^{2} \mathrm{bA}$ \\
\hline AC5058 & $0.788^{1}(58.31)^{2} \mathrm{aA}$ & $0.508^{1}(30.26)^{2} \mathrm{aB}$ \\
\hline AC 5056 (light seed) & $0.566^{1}(33.70)^{2} \mathrm{bA}$ & $0.269^{1}(7.12)^{2} \mathrm{bB}$ \\
\hline AC 5056 (dark seed) & $0.952(77.90)^{2} \mathrm{aA}$ & $0.351^{1}(12.67)^{2} \mathrm{bB}$ \\
\hline
\end{tabular}

Means followed by the same lowercase letter in the column and uppercase letter in the rows do not differ from each other by the Scott-Knott test at $5 \%$ probability.

${ }^{1}$ Transformed data (arcsine of the square root of $\mathrm{x} / 100$ ). ${ }^{2}$ Original data. al., 2014). It is an important vigor test because the faster the seed germination is, the faster its development and, therefore, the shorter the time of the initial stage, when plants are more vulnerable to external agents that could harm them.

The first germination count was similar in the evaluations carried out in both years for most genotypes, except for Vanda, Mônica, and both AC 5056, which presented a worse performance in 2017 (Table 6). The genotypes Cinderela and AC 5053 had the lowest percentage of normal seedlings germinated on the fourth day of evaluation when compared to the other genotypes in the first year. In the evaluations of 2017, both genotypes AC 5056, AC 5053, and Mônica had the worst performance.

The first germination count has been used as a vigor test due to its simplicity and possibility of being conducted together with the germination test. According to Nakagawa (1999), in the first germination count test, all normal seedlings that are well-developed and morphologically perfect, without cracks or lesions, are removed and computed as strong (vigorous) normal. Treatments whose seeds have a higher percentage of strong normal seedlings are considered more vigorous, i.e., they are more likely to emerge and produce normal plants under adverse conditions in the field.

Seedling dry matter of the genotypes Cubana, Grand Rapids of the Embrapa germplasm bank, both AC 5056, and Vanda showed similar behavior in both years. Among the genotypes that showed behavioral differences in 2016 and 2017, the

Table 6. Means of first germination count (\%) of ten lettuce genotypes grown under organic management in 2016 and 2017 at UFMG.

\begin{tabular}{ccc}
\hline Genotype & \multicolumn{2}{c}{ Means } \\
\cline { 2 - 3 } & 2016 & 2017 \\
\hline $\begin{array}{c}\text { Grand Rapids } \\
\text { (Embrapa) }\end{array}$ & $0.74^{1}(51.75)^{2} \mathrm{aA}$ & $0.59^{1}(40.0)^{2} \mathrm{aA}$ \\
Grand Rapids & $0.73^{1}(51.5)^{2} \mathrm{aA}$ & $0.81^{1}(61.0)^{2} \mathrm{aA}$ \\
(commercial) & $0.77^{1}(56.25)^{2} \mathrm{aA}$ & $0.30^{1}(12.5) 2 \mathrm{bB}$ \\
Mônica & $0.70^{1}(47.25)^{2} \mathrm{aA}$ & $0.48^{1}(31.5)^{2} \mathrm{aA}$ \\
Cubana & $0.54^{1}(28.5)^{2} \mathrm{bA}$ & $0.44^{1}(25.5)^{2} \mathrm{aA}$ \\
Cinderela & $0.89^{1}(70.5)^{2} \mathrm{aA}$ & $0.48^{1}(27.0)^{2} \mathrm{aB}$ \\
Vanda & $0.38^{1}(18.5)^{2} \mathrm{bA}$ & $0.27^{1}(8.0)^{2} \mathrm{bA}$ \\
AC5053 & $0.76^{1}(54.25)^{2} \mathrm{aA}$ & $0.52^{1}(31.0)^{2} \mathrm{aA}$ \\
AC5058 & $0.73^{1}(51.5)^{2} \mathrm{aA}$ & $0.151^{1}(3.5)^{2} \mathrm{bB}$ \\
AC 5056 (light seed) & $0.88^{1}(69.75)^{2} \mathrm{aA}$ & $0.38^{1}(15.0)^{2} \mathrm{bB}$ \\
AC 5056 (dark seed) &
\end{tabular}

Means followed by the same lowercase letter in the column and uppercase letter in the rows do not differ from each other by the Scott-Knott test at $5 \%$ probability. ${ }^{1}$ Transformed data (arcsine of the square root of $\mathrm{x} / 100$ ). ${ }^{2}$ Original data. 
Table 7. Means of dry matter (g) of ten lettuce genotypes grown under organic management in 2016 and 2017 at UFMG.

\begin{tabular}{ccc}
\hline Genotype & 2016 & 2017 \\
\cline { 2 - 3 } & $0.579 \mathrm{bA}$ & $0.454 \mathrm{aA}$ \\
$\begin{array}{c}\text { Grand Rapids } \\
\text { (Embrapa) }\end{array}$ & $0.207 \mathrm{cB}$ & $0.525 \mathrm{aA}$ \\
$\begin{array}{c}\text { Grand Rapids } \\
\text { (commercial) }\end{array}$ & $0.014 \mathrm{cB}$ & $0.380 \mathrm{aA}$ \\
Mônica & $0.613 \mathrm{bA}$ & $0.319 \mathrm{aA}$ \\
Cubana & $1.398 \mathrm{aA}$ & $0.348 \mathrm{aB}$ \\
Cinderela & $0.308 \mathrm{cA}$ & $0.421 \mathrm{aA}$ \\
Vanda & $0.512 \mathrm{bA}$ & $0.027 \mathrm{bB}$ \\
AC5053 & $0.651 \mathrm{bA}$ & $0.329 \mathrm{aB}$ \\
AC5058 & $0.017 \mathrm{cA}$ & $0.085 \mathrm{bA}$ \\
AC 5056 (light seed) & $0.384 \mathrm{bA}$ & $0.124 \mathrm{bA}$ \\
AC 5056 (dark seed) &
\end{tabular}

Means followed by the same lowercase letter in the column and uppercase letter in the rows do not differ from each other by the Scott-Knott test at $5 \%$ probability.

commercial Grand Rapids and Mônica had better results in the evaluations carried out in 2017; the others genotypes had the best results in 2016 (Table 7).

Dry matter is a parameter of vigor evaluation and seedlings that present a higher weight have higher vigor and physiological quality (Gama et al., 2010). Vigorous seeds provide a higher transfer of dry matter from their reserve tissues to the embryonic axis in the germination stage, and this transfer is responsible for producing seedlings with a higher weight due to a higher dry matter accumulation (Nakagawa, 1999).

The genotype Cinderela was superior to the other in the determination of vigor of seedling dry matter in the planting evaluation of 2016. Planting determinations of 2017 showed that the genotypes AC 5053 and both AC 5056 had a worse behavior when compared to the other genotypes.

Dry matter determination is a way of evaluating plant growth and determining the transfer of dry matter from reserve tissues to the embryonic axis with some accuracy. Vigorous seeds provide a higher transfer of dry matter from their reserve tissues to the embryonic axis at the germination stage, originating seedlings with a higher weight (Nakagawa, 1999).

\section{Conclusions}

The genotype Cubana and both Grand Rapids had higher yields in both conditions tested.

Seed quality was influenced by genotypes and years, showing a considerable variation in the quality tests.
Both genotypes Grand Rapids stood out in the germination results. Regarding the vigor tests, the genotypes Vanda and AC 5058 stood out in the tests of GRI and first germination count, while Cinderela stood out in the test of seedling dry matter.

The tested genotypes were promising for seed production under organic management.

\section{References}

ABCSEM. ASSOCIAÇÃO BRASILEIRA DE COMÉRCIO DE SEMENTES E MUDAS. $3^{\circ}$ Seminário Nacional de Folhosas, 2018. Available on: <http://www.abcsem.com.br/upload/arquivos/2-Ayrton Tullio.pdf $>$. Accessed on April $9^{\text {th }}, 2019$.

BRASIL. Ministério da Agricultura, Pecuária e Abastecimento. Regras para análise de sementes. Ministério da Agricultura, Pecuária e Abastecimento. Secretaria Nacional de Defesa Agropecuária. Brasília: MAPA/ACS, 2009. 395p. http://www.agricultura.gov.br/assuntos/ insumos-agropecuarios/arquivos-publicacoes-insumos/2946_regras_ analise__sementes.pdf.

BRASIL. Ministério da Agricultura, Pecuária e Abastecimento. Orgânicos. Brasília, DF: MAPA, 2014. Available on: <http:// www.agricultura.gov.br/desenvolvimento-sustentavel/organicos $>$. Accessed on January $15^{\text {th }}, 2017$.

BRASIL. Ministério da Agricultura, Pecuária e Abastecimento MAPA. Mercado brasileiro de orgânicos deve movimentar $R \$ 2,5$ bi em 2016. Brasília, 2015. Available on <http://seer.sct.embrapa.br/ index.php/pab/about/submissions\#authorGuidelines $>$. Accessed on January $15^{\text {th }}, 2018$.

CATÃO, H.C.R.M.; GOMES, A.L.A.; SANTOS, H.O.S.; GUIMARÃES, R.M.; FONSECA, P.H.F.; CAIXETA, F. Aspectos fisiológicos e bioquímicos da germinação de sementes de alface em diferentes temperaturas. Pesquisa Agropecuária Brasileira, v.49, n.4, p.316-322, 2014. http://www.scielo.br/pdf/pab/v49n4/0100204X-pab-49-04-0316.pdf

CFSEMG. COMISSÃO DE FERTILIDADE DO SOLO DO ESTADO DE MINAS GERAIS. Recomendações para o uso de corretivos e fertilizantes em Minas Gerais: $5^{\mathrm{a}}$ aproximação. Secretaria de Agricultura do Estado de Minas Gerais, 1999. p.359.

GAMA, J.S.N.; MONTE, D.M.O.; ALVES, E.U.; BRUNO, R.L.A.; BRAGA-JÚNIOR, J.M. Temperaturas e substratos para germinação e vigor de sementes de Euterpe oleracea Mart. Revista Ciência Agronômica, v.41, n.4, p.664-670, 2010. http://www.scielo.br/scielo. php?script $=$ sci_arttext\&pid=S1806-66902010000400021\&lng=pt\& nrm $=$ iso\&tlng $=$ pt

KANO, C.; CARDOSO, A.I.I.; HIGUTI, A.R.O.; BÔAS, R.L.V. Doses de potássio na produção e qualidade de sementes de alface. Horticultura Brasileira, v.24, n.3, p.356-359, 2006. http://www. scielo.br/pdf/hb/v24n3/17.pdf

MAGUIRE, J.D. Speed of germination aid in selection and evaluation for seedling emergence and vigor. Crop Science, v.2, n.2, p.176-77, 1962. https://dl.sciencesocieties.org/publications/cs/ abstracts/2/2/CS0020020176/preview/pdf 
NASCIMENTO, W.M.; MELO, P.C.T. Desafios e oportunidades na produção de sementes de hortaliças no Brasil. Seed News, ano XIX, n.3, maio/jun, 2015. Available on: <http://www.seednews.inf. br/_html/site/content/reportagem_capa/index.php?edicao $=116>$. Accessed on January $19^{\text {th }}, 2018$.

NASCIMENTO, W.M.; DIAS, D.C.F.S.; SILVA, P.P. Qualidade da semente e estabelecimento de plantas de hortaliças no campo. In: NASCIMENTO, W.M. (Ed.). Hortaliças: tecnologia de produção de sementes. Brasília: Embrapa Hortaliças, 2011. p.79-106.

NAKAGAWA, J. Testes de vigor baseados no desempenho de plântulas. In: KRZYZANOWSKI, F. C.; VIEIRA, R.D.; FRANÇANETO, J.B. (Ed.). Vigor de sementes: conceitos e testes. Londrina: ABRATES, 1999. p.1-24.

RITTER, M.C.; YAMASHITA, O.M.; CARVALHO, M.A.C. Efeito de extrato aquoso e metanólico de nim (Azadiracta indica) sobre a germinação de alface. Multitemas, v.1, n.46, p.9-21, 2014. http:// www.multitemas.ucdb.br/article/view/168

SEDIYAMA, M.A.N.; SANTOS, I.C.; LIMA, P.C. Cultivo de hortaliças no sistema orgânico. Ceres, v.61, supl., p.829-837, 2014. http://www.scielo.br/scielo.php?script=sci_arttext\&pid=S0034$737 X 2014000700008 \& \operatorname{lng}=\mathrm{pt} \& \operatorname{lng}=\mathrm{pt}$
TAYLOR, A.C. Seed storage, germination and quality. In: WIEN, H.C. (Ed.). The physiological of vegetable crops. New York: Wiley, 1997. p.1-36.

VIEIRA, M.G.G.C.; VON PINHO, E.V.R.; SALGADO, K.C.P.C. Técnicas moleculares em sementes. Informe Agropecuário, v.27, n.232, p.88-96, 2006.

VIGGIANO, J. Produção de sementes de alface. In: CASTELLANE, P.D. (Ed.). Produção de sementes de hortaliças. Jaboticabal: FCAV/ FUNEP, 1990. p.1-15.

VILLELA, R.P.; SOUZA, R.J.; GUIMARÃES, R.M.; NASCIMENTO, W.M.; GOMES, L.A.A.; CARVALHO, B.O.; BUENO,A.C.R. Produção e desempenho de sementes de cultivares de alface em duas épocas de plantio. Revista Brasileira de Sementes, v.32, n.1, p.158-169, 2010. http://www.scielo.br/scielo.php?script=sci_arttext\&pid=S0101$31222010000100018 \& \operatorname{lng}=\mathrm{pt} \& \operatorname{lng}=\mathrm{pt}$ 